\title{
The Use of Mediation as an Alternative in Banking Dispute Resolve
}

\author{
Ferroka ${ }^{1}$, Rineke Sara ${ }^{2}$ \\ Doctoral of Law, Universitas Borobudur Jakarta \\ $\left\{\right.$ ferrokaunbor@gmail.com ${ }^{1}$, rineke_sara@borobudur.ac.id $\left.{ }^{2}\right\}$
}

\begin{abstract}
In dispute resolution, there are two settlement procedures, firstly, through litigation (court), and secondly, through non-litigation (outside court), which are known as alternative dispute resolution. One of the alternative forms of dispute resolution is mediation. In Indonesia, there are two models of mediation institutions, namely mediation institutions in court (litigation) and mediation institutions that are held outside the court (non-litigation) as part of an alternative method of dispute resolution. In dispute resolution of the banking world, there's known as banking mediation. Banking mediation is an alternative to banking dispute resolution, which is a simple, inexpensive, and fast way to resolve problems that occur between customers and banks. Also, the result of mediation, which is an agreement between the customer and the bank, is perceived as an effective form of problem-solving because both the customer's interests and the bank's reputation can be safeguarded.
\end{abstract}

Keywords: Mediation; Banking Dispute Resolution

\section{Introduction}

There has been economic globalization that demands legal adjustments according to the needs of the times. Including demands against banking legal needs in line with the acceleration of legal problems in the form of banking disputes which are increasing every year. To overcome this, we need a legal instrument that can answer these problems. Apart from that, alternatives for banking dispute resolution that are considered ideal without harming the disputing parties are required. One of the alternatives for banking dispute resolution is banking mediation. The implementation of banking mediation is necessary to resolve disputes between customers and banks which, if not implemented, have the potential to harm the interests of customers and affect the reputation of the bank.

In Indonesia, the banking mediation function has been carried out by Bank Indonesia since the issuance of PBI No. 8/5 / PBI / 2006 concerning Banking Mediation on January 30, 2006, with the consideration that the settlement of complaints by banks that do not satisfy customers has the potential to lead to banking disputes. In this case, if the dispute is not handled immediately, in the long term it will affect the level of public trust in banking institutions so that facilitation is needed through banking mediation to facilitate the settlement of banking disputes. 
Until the end of 2007, the banking mediation institution that should have been established by the banking association could not be realized due to various factors, including funding and human resources. With this in mind, Bank Indonesia issued Bank Indonesia Regulation Number 10/1 / PBI / 2008 concerning Amendments to Bank Indonesia Regulation Number 8/5 / PBI / 2006 concerning Banking Mediation, whereby Bank Indonesia will continue to carry out the banking mediation function after 2007.

In line with the implementation of the banking mediation function, Bank Indonesia together with banking associations will continue to strive to establish an independent banking mediation institution. If an independent banking mediation institution has been established, Bank Indonesia will transfer the banking mediation function which has been handled to the banking mediation institution.

The importance of banking mediation is that as an alternative to solving banking disputes, it is a simple, inexpensive, and fast way to resolve problems that occur between customers and banks. Besides, the result of mediation, which is an agreement between the customer and the bank, is seen as an effective form of problem-solving because both the customer's interests and the bank's reputation can be safeguarded.

Based on the above background, it is important to use mediation as an alternative in solving banking disputes. It is important to research, to be more focused and in-depth from the perspective of legal science in the form of using mediation as an alternative in solving banking disputes from a statutory perspective.

\section{Research Problem}

According to the background that has been explained above, the research problem can be formulated as below:

How is the use of mediation as an alternative in banking dispute resolution?

\section{Research Method}

Legal research is a scientific activity, which is based on methods, systematics, and certain thoughts, which propose to study one or several phenomena of certain laws, by analyzing them [1]. This research is normative legal research. The approach used is the statute approach and the conceptual approach [2]. The statute approach is carried out by examining all rules and regulations relating to the legal issues being handled. A conceptual approach (conceptual approach) is performed by using concepts related to the problems analyzed in this study.

\section{Results and Discussion}

Etymologically, the term mediation comes from Latin, mediare which means "being in the middle". This meaning refers to the role played by a third party as a mediator in carrying out its duties to mediate and resolve disputes between the parties. "Being in the middle" also means that the mediator must be neutral and impartial in resolving disputes [3].

In fact, in Indonesia, mediation is not a new thing, since a long time ago the Indonesian people have implemented a pattern of dispute resolution through mediation. It's just that the community knows him by the term deliberation for consensus. The community chooses traditional, religious, or community leaders who have authority and entrusted them as 
mediators in resolving disputes in society. The application of mediation as a means of resolving disputes is following the philosophical values of the Indonesian nation, namely Pancasila, more precisely the fourth precept.

In the history of justice in Indonesia, it is known that there is dispute resolution similar to mediation, namely peaceful efforts that must be taken by judges in examining, hearing, and deciding civil cases. The provisions governing peace efforts are regulated in Article $130 \mathrm{HIR} /$ $154 \mathrm{RBg}[4]$.

In law, dispute resolution such as banking can be resolved in two ways, namely through litigation (court) or non-litigation (outside the court). Litigation is the process of resolving legal disputes in court where each disputing party has the same rights and obligations to files a lawsuit and dispute the lawsuit through answers [5]. In addition to the litigation, dispute resolution can also be resolved through non-litigation (out of court), which in America is usually referred to as an Alternative Dispute Resolution (ADR). Meanwhile in Indonesia, it is known as Alternatif Penyelesaian Sengketa or APS [6].

According to Law Number 30 of 1999 concerning Arbitration and Alternative Dispute Resolution, Article 1 point 10 states "alternative dispute resolution is a dispute settlement institution or difference of opinion through a procedure agreed by the parties, namely settlement outside the court through consultation, negotiation, mediation, conciliation, or expert judgment". APS, in general, can only be carried out in civil cases, but cannot be applied in criminal cases. One form of APS referred to in Law Number 30 of 1999 is mediation.

The definition of litigation mediation according to the Supreme Court Regulation (PERMA) Number 1 of 2016 concerning Mediation Procedures in Courts, Article 1 paragraph (1) which states: "Mediation is a method of dispute resolution through a negotiation process to obtain an agreement between the Parties with the assistance of a mediator".

According to Bank Indonesia Regulation Number 8/5 / PBI / 2006 concerning Banking Mediation, Article 1 point 4, mediation is a dispute resolution process involving a mediator to assist the disputing parties to settle in the form of a voluntary agreement on some or all of the disputed issues. A mediator is a party that does not take sides in assisting the implementation of mediation.

Gary Goodpaster defines mediation as a problem-solving negotiation process in which an impartial and neutral outside party works with the disputing parties to help them reach a satisfactory agreement [7]. According to John W Head, mediation is a mediation procedure in which a person acts as a vehicle to communicate between the parties so that their different views on the dispute can be understood and possibly reconciled, but the main responsibility for achieving a sense of peace remains with the parties themselves [8].

\subsection{Legal Basis of Mediation}

Mediation legal basis is one of Alternative Dispute Resolution (ADR) in Indonesia such as:

a. Pancasila, apart from being the basis and ideology of the Indonesian nation and state, is also a legal ideal that has one of the principles of deliberation for consensus.

b. The 1945 Constitution is the constitution of the Indonesian state in which the principle of deliberation for consensus animates the articles in it.

c. Law Number 14 of 1970 concerning Basic Provisions of Judicial Power, which has been amended to Law Number 4 of 2004 explains Article 3 of the statement: "Settlement of cases outside the court, based on peace or through a referee is still allowed". Apart from 
that Article 2 paragraph (4) statement: the provisions of paragraph 1 do not preclude the possibility of settling civil cases for peace.

d. Law Number 48 of 2009 concerning Judicial Power, Chapter XII concerning Out-of-Court Dispute Resolution, Article 58 and Article 60 which regulates mediation. Article 58 states that: "civil dispute resolution efforts can be carried out outside the state court through arbitration or alternative dispute resolution". Article 60 paragraph (1) states that: "Alternative dispute resolution is a dispute resolution institution or difference of opinion through a procedure agreed upon by the parties, namely settlement outside the court through consultation, negotiation, mediation, conciliation or expert judgment".

e. Law Number 30 of 1999 concerning Arbitration and Alternative Dispute Resolution Article 6 states: "Disputes or civil differences of opinion can be resolved by the parties through alternative dispute resolution based on good faith by overriding litigation in the District Court".

f. Supreme Court Circular (SEMA) Number 1 of 2002 concerning Empowerment of First Level Courts to Implement Peace Institutions. SEMA instructed its subordinate judiciary, especially the court of the first instance, namely the District Court to further maximize the application of peace efforts to the litigating parties as in Article $130 \mathrm{HIR} / 154 \mathrm{Rbg}$.

g. Supreme Court Regulation (PERMA) Number 2 of 2003 concerning Mediation Procedures in Courts, that mediation is only applied in the First Level Courts within the General Court.

h. Supreme Court Regulation (PERMA) Number 1 of 2008 concerning Mediation Procedures in Courts. According to PERMA, mediation is also required to be carried out in the Religious Courts.

i. Supreme Court Regulation (PERMA) Number 1 of 2016 concerning Mediation Procedures in Courts as the latest regulation on mediation.

In addition to the legal basis above, the settlement of disputes outside the court is regulated in:

a. Article 1851 of the Civil Code states: "Peace is an agreement in which both parties by handing over, ensuring or withholding an object, terminating a pending case or preventing the occurrence of a case This agreement is not valid, but is made in writing".

b. Article 1855 of the Civil Code: "Every peace only ends disputes contained therein, whether the parties express their intentions in special or general words, or the intention can be concluded as the only absolute result of what is written".

c. Article 1858 of the Civil Code: "All peace has between the parties a power like a judge's decision at the final stage. This agreement cannot be denied on the grounds of an error regarding the law or because one of the parties was disadvantaged".

Based on the explanation above, it can be seen that in Indonesia there are two models of mediation institutions, namely mediation institutions in court (litigation) and mediation institutions that are held outside the court (non-litigation) as part of an alternative method of dispute resolution.

Law Number 30 of 1999 concerning Arbitration and Alternative Dispute Resolution, has further emphasized the existence of a mediation institution as an alternative dispute resolution institution. Article 1 point 10 states: "Alternative dispute resolution is a dispute settlement institution or difference of opinion through a procedure agreed by the parties, namely the settlement of disputes outside the court through consultation, negotiation, mediation, conciliation, or expert judgment". However, this Law does not regulate and provide a more detailed definition of these alternative institutions, as it provides for Arbitration. 


\subsection{Banking Mediation}

It has been explained earlier that banking mediation as an alternative to banking dispute resolution is a simple, inexpensive, and fast way to resolve problems that occur between customers and banks.

According to PBI Number 8/5 / PBI / 2006 concerning Banking Mediation, Article 1 point 4 is defined as a dispute is a problem submitted by a customer or customer representative to a bank mediation organizer, after going through a complaint resolution process by the Bank as regulated in the Bank Indonesia Regulation on Settlement of Customer Complaints.

Banks referred to are Commercial Banks and Rural Banks as referred to in Law Number 7 of 1992 concerning Banking as amended by Law Number 10 of 1998, including branch offices of foreign banks [9]. Meanwhile, customers are parties who use the Bank's services, including parties who do not have an account but use the Bank's services to conduct financial transactions (walk-in customers) [10].

Please note that not all banking disputes can be resolved through mediation. Here, disputes that can be resolved through mediation based on PBI Number 8/5 / PBI / 2006 concerning Banking Mediation are disputes between customers and banks due to the failure to meet the customer's financial demands by the bank in solving customer complaints, resolving them through banking mediation [11]. Banking mediation is only performed for any dispute that has a financial claim value of no more than Rp. 500,000,000.00 (five hundred million rupiahs). Besides, customers cannot file financial claims due to immaterial losses [12]. This implies that disputes with financial demands of more than Rp. 500,000,000.00 (five hundred million rupiahs) cannot be mediated and cannot file immaterial claims. Regarding this matter, dispute resolution is conducted through litigation, namely filing a dispute case to court.

\subsection{Mediation Submission Procedures}

To settle banking disputes through mediation, the customer first submits a dispute settlement to the Directorate of Banking Investigation and Mediation, Bank Indonesia, Jalan M.H. Thamrin Number 2, Jakarta 10350 [13]. Submission of dispute resolution in the framework of banking to Bank Indonesia mediation carried out by the customer or customer representative. If a customer or a customer representative submits a dispute resolution to Bank Indonesia, the Bank is required to comply with the summons of Bank Indonesia [14]. The customer representative is an individual, institution, or legal entity acting for and on behalf of clients with a special power of attorney by the client [15].

Submission of dispute resolution must meet the following requirements [16]:

a. Submitted in writing, accompanied by adequate supporting documents;

b. The customer has ever submitted an attempt for the resolution to the bank;

c. The proposed dispute is not in process or has never been decided by an arbitration institution or court, or there has been no agreement facilitated by another mediation institution;

d. The proposed dispute is a civil dispute;

e. The proposed dispute has never been processed in banking mediation facilitated by Bank Indonesia; and 
f. Submission of dispute resolution does not exceed 60 (sixty) working days since the date of the result of the settlement of complaints submitted by the bank to customers.

\subsection{Mediation Process}

The banking mediation function carried out by Bank Indonesia is limited to assisting customers and banks in reviewing disputes fundamentally to obtain an agreement. According to Bank Indonesia Regulation Number 8/5 / PBI / 2006, Article 5 states that to carry out the banking mediation function, Bank Indonesia shall appoint a mediator. Mediators must qualify at least as follows:

a. Acknowledge banking, finance, and or the law;

b. Has no financial or other interest in dispute resolution; and

c. Does not have a blood or blood relationship up to the second degree with the customer or customer representative and the bank.

Furthermore, Article 9 of the same rule states that the mediation process is carried out after the customer or customer representative and the Bank have signed an agreement to mediate which contains:

a. Agreement to choose mediation as an alternative to dispute resolution; and

b. Agreement to comply with and comply with the mediation rules stipulated by Bank Indonesia

After the mediation agreement signing process, the Bank is obliged to follow and obey the mediation agreement that has been signed by the customer or customer representative and the Bank. Furthermore, in Bank Indonesia Regulation No. 8/5 / PBI / 2006, Article 10 explains that the customer and the Bank can authorize other parties in the mediation process. The power of attorney is granted by a particular power of attorney that at least states the authority of the recipient of authority to make decisions.

The mediation process until the signing of the Agreement Deed is carried out within a maximum period of 30 (thirty) working days after the customer or customer representative and the Bank have signed an agreement to mediate. The mediation process period can be extended up to another 30 (thirty) working days based on the agreement of the customer or customer representative and the Bank.

\subsection{Mediation Agreement}

If during the mediation process an agreement has been reached, namely a joint agreement between the customer or customer representative and the Bank on an attempt to resolve a dispute, the agreement shall be outlined in the form of an Agreement Deed. The Agreement Deed is a written document containing a final and binding agreement for the customer and the Bank [17].

After an agreement occurs between the customer or customer representative and the Bank resulting from the mediation process as outlined in the Agreement Deed signed by the customer or customer representative and the Bank. Furthermore, the Bank is obliged to carry out the results of the settlement of banking disputes between the customer and the Bank which have been agreed upon and outlined in the Agreement Deed [18].

The result of mediation, which is an agreement between the customer and the bank, is seen as an effective form of problem resolution because both the customer's interests and the bank's reputation can be safeguarded. Thus, the banking mediation function carried out by Bank Indonesia was limited to providing space, assisting customers and banks to raise the main 
issues at issue, providing resource persons, and seeking to reach an agreement for dispute resolution between the customer and the bank.

\section{Conclusion and Suggestion}

\subsection{Conclusion}

The existence of Bank Indonesia Regulation No. 8/5 / PBI / 2006 concerning Banking Mediation which was later changed to Bank Indonesia Regulation No. 10/1 / PBI / 2008 is a special regulation governing banking mediation, which so far has not been specifically regulated in the laws and regulations in Indonesia. Although this regulation still needs to be improved, at least temporarily it can help resolve banking disputes without having to go through court channels. The use of mediation is a simple, inexpensive, and fast method. Also, the result of mediation, which is an agreement between the customer and the bank, is seen as an effective form of problem resolution because both the customer's interests and the bank's reputation can be safeguarded.

\subsection{Suggestions}

a. Efforts are needed to immediately establish a banking mediation institution mandated by Bank Indonesia Regulation Number 8/5 / PBI / 2006 concerning Banking Mediation.

b. The nominal value of the terms of dispute resolution through mediation should be increased by more than Rp. 500,000,000, - and the venue for the mediation should be in the provincial capital where there is a representative of Bank Indonesia before the establishment of the mediation institution.

c. The existing regulations need to be improved into laws because no law specifically regulates banking mediation.

\section{References}

[1] Soekanto, Soerjono.: Pengantar Penelitian Hukum. Universitas Indonesia, Jakarta (2006).

[2] Marzuki, Peter Mahmud.: Penelitian Hukum. Edisi Revisi. Prenada Kencana, Jakarta (2014).

[3] Abbas, Syahrizal.: Mediasi dalam Hukum Syariah, Hukum Adat, dan Hukum Nasional. Kencana, Jakarta (2011).

[4] Abbas, Syahrizal.: Mediasi dalam Hukum Syariah, Hukum Adat, dan Hukum Nasional. Kencana, Jakarta (2011).

[5] Nadia, Yessi.: Penyelesaian Sengketa Litigasi dan Non-Litigasi (Tinjauan Terhadap Mediasi dalam Pengadilan sebagai Alternatif Penyelesaian Sengketa di Luar Pengadilan). Retrieved from https://www.academia.edu/29831296/Penyelesaian_Sengketa_Litigasi_dan_NonLitiga si Tinjauan_terhadap_Mediasi_dalam_Pengadilan_sebagai_Alternatif

[6] Usmani, Rachmadi.: Mediasi di Pengadilan: Dalam Teori dan Praktik. Sinar Grafika, Jakarta (2012). 
[7] Umam, Khotibul.: Penyelesaian Sengketa Di Luar Pengadilan. Pustaka Yustisia, Yogyakarta (2010).

[8] Head, John W.: Pengantar Umum Hukum Ekonomi. Proyek ELIPS, Jakarta (1997)

[9] Peraturan Bank Indonesia Nomor 8/5/PBI/2006 tentang Mediasi Perbankan.

[10] Peraturan Bank Indonesia Nomor 8/5/PBI/2006 tentang Mediasi Perbankan.

[11] Peraturan Bank Indonesia Nomor 8/5/PBI/2006 tentang Mediasi Perbankan.

[12] Peraturan Bank Indonesia Nomor 8/5/PBI/2006 tentang Mediasi Perbankan.

[13] Peraturan Bank Indonesia Nomor 10/1/PBI/2008 tentang Perubahan Atas Peraturan Bank Indonesia Nomor 8/5/PBI/2006 tentang Mediasi Perbankan.

[14] Peraturan Bank Indonesia Nomor 8/5/PBI/2006 tentang Mediasi Perbankan.

[15] Peraturan Bank Indonesia Nomor 8/5/PBI/2006 tentang Mediasi Perbankan.

[16] Peraturan Bank Indonesia Nomor 8/5/PBI/2006 tentang Mediasi Perbankan.

[17] Peraturan Bank Indonesia Nomor 8/5/PBI/2006 tentang Mediasi Perbankan.

[18] Peraturan Bank Indonesia Nomor 8/5/PBI/2006 tentang Mediasi Perbankan. 